\title{
Estimation of Potential of the Ground Water Arsenic Contamination in Sanandaj Area Using Artificial Neural Network Model
}

\author{
Saman Moradi ${ }^{1}$, Jamil Amanoallahii ${ }^{2 *}$, Farshid Ghorbani ${ }^{2}$ \\ 1. M.Sc. Student, Environment Science, Faculty of Natural Resources, University of Kurdistan, Sanandaj, Iran \\ 2. Assistant Professor, Department of Environmental Sciences, Faculty of Natural Resources, University of \\ Kurdistan, Sanandaj, Iran \\ *E-mail: j.amanollahi@uok.ac.ir
}

Received: 17 Jun. 2018 P ; Accepted: 26 Sep. 2018

\begin{abstract}
Background \& objective: Identification of ground waters contaminated by arsenic using surface soil parameters and modeling this relationship in two models including artificial neural network and multiple linear regression can be useful in managing the water resources of the region.

Material \& methods: The purpose of the present study was to estimate the potential of arsenic pollution in the Sanandaj ground waters using multiple linear regression (MLR) and artificial neural network (ANN) models. In this regards, 35 number of wells were selected among the permissible wells with considering watershed area, appropriate distribution, and different geological structure. The water samples stored in polyethylene bottles and kept at $4^{\circ} \mathrm{C}$ until transferred to the laboratory. For consideration of the relationship between the soils characteristics around the wells and ground water, the soil samples were collected from $0-20 \mathrm{~cm}$ of topsoil with composite sampling technique. The soil samples were air-dried and prepared for analysis. For long term storage of water samples nitric acid were added and the concentration of arsenic in water samples were measured by graphite furnace atomic absorption analyzer. Physical and chemical characteristics of the soil samples including: arsenic, arsenate, arsenite, phosphate, nitrate, total iron, amorphous iron, total manganese, amorphous manganese, clay, sand, silt, organic matter, $\mathrm{pH}$ and CEC were measured. Then all water and soil data were normalized and finally, accuracy of the MLP and ANN models was assessed to investigate the relationship between arsenic of water and soil parameters.

Results: Results showed that the arsenic concentration of ground waters were lower than the standard level in the study area. This can be due to high concentration of arsenate in the study area soils compared arsenite and increasing the cationic exchange capacity of soil under the influence of clay particles, organic matter and free iron oxides.

Conclusion: Compression of models accuracy result showed that ANN model with $\mathrm{R}=0.835$, $\mathrm{RMSE}=0.156$ and $\mathrm{MAE}=0.118$ in the training phase and $\mathrm{R}=0.816, \mathrm{RMSE}=0.177$ and $\mathrm{MAE}=0.158$ in the testing phase has higher accuracy and lower errors in the estimation of ground waters arsenic contamination than MLP model.
\end{abstract}

Keywords: Arsenic, Groundwater, Multiple linear regression, Artificial neural network. Arsenate 


\title{
برآورد يتانسيل آلود با استفاده از مدل شبكه عصبى مصنوعى
}

\author{
سامان مرادى'، جميل امان اللهى"“"، فرشيد قربانى ' \\ ' ل دانش آموخته كارشناسى ارشد، محيط زيست، دانشكده منابع طبيعى، دانشكاه كردستان، سناند، ايران

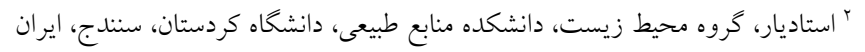

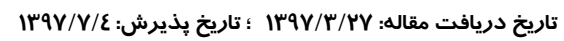

קكيده

زمينه و هدف: شناسايى آبهاى زيرزمينى آلوده به آرسنيك با استفاده از بارامترهاى سطحى خاك و مدلســازي ايسن

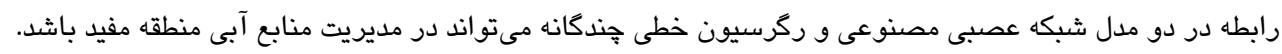

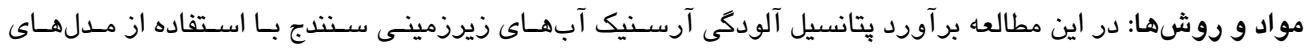

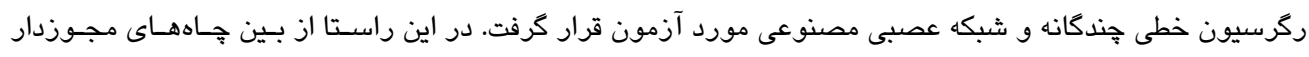

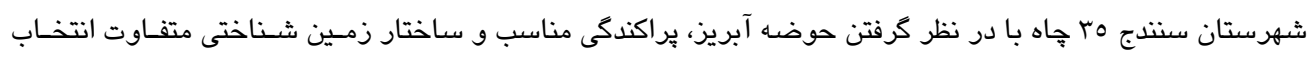

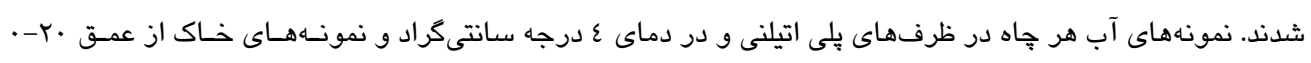

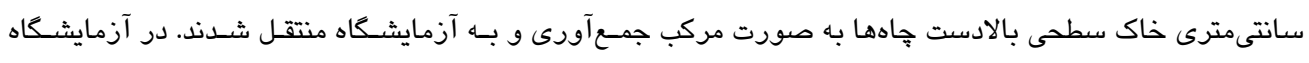

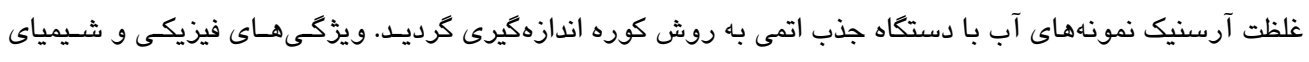

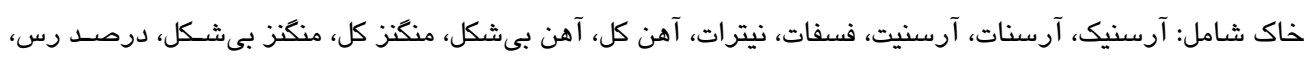

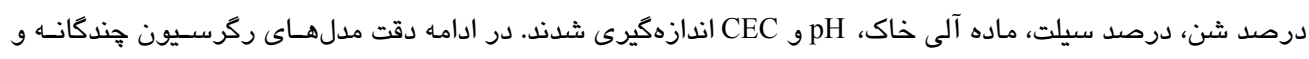

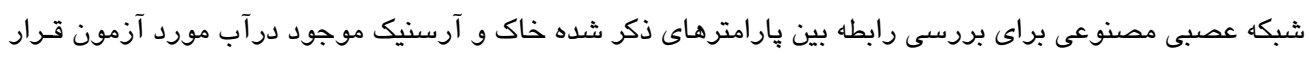
كرفت.

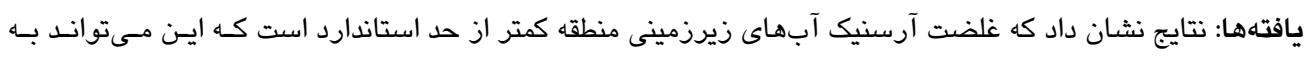

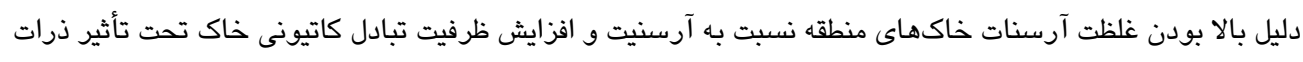
رس، ماده آلى و اكسيدهاى آزاد آهن باشد.

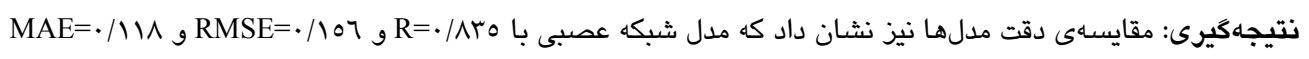

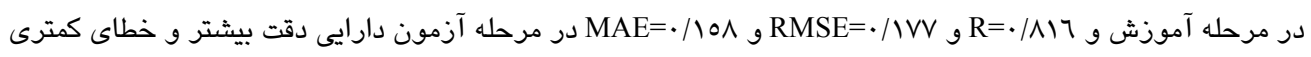
در برآورد آلودكى آرسنيك آبهاى زيرزمينى نسبت به مدل ركرسيون خطى هندكانه است. كلمات كليدى: آرسنيك، آبهاى زيرزمينى، ركرسيون خطى جندكانه، شبكه عصبى. آرسنات 
جامعه شود. استفاده از روشهاى سنتى براى بررسى وضسعيت

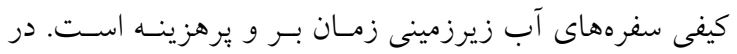
سالهاى اخير، روشهاى متنوعى در زمينه مديريت بهتر براى

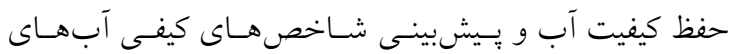

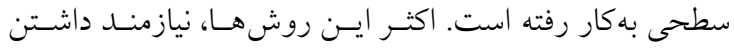
اطلاعات وسيعى از فرايندهاى هيدرولوزيكى متفاوت است كه

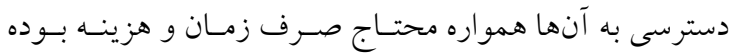
مدل ركرسيون خطى جندكانه (MLR) روشسى اسـت كـه. براى ارتباط خطى بين يكى متغير وابسته و يكى يا خنــــ متغيــر

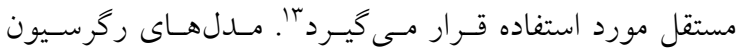

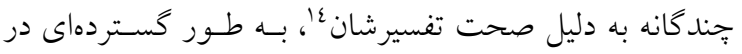
زمينهى بيشبينى آلودخىهاى محيط زيست مورد استفاده قرار

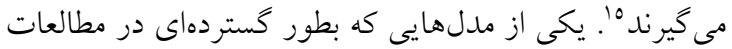

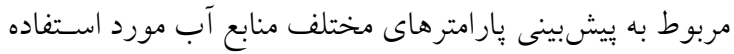
قرار كرفته و يزوهشكران بر دقت بالاى اين روش در مقايسه با بان روابط تجربى و رگرسيونى تاكيد نمودهاند مدل شـبكه عصـبى مصنوعى است17'. شبكه عصبى مصـنوعى زيــر مجموعسهاى از تكنيكهاى هوش مصنوعى است كـه سـاختار و عملكــرد آن بهصـورت كلسى همانـــ مغـز انسـان اسـت. كـه بـه صـورت بيشرونده و موفق براى سيستمهـاى غيرخطى در زمينـههـاى

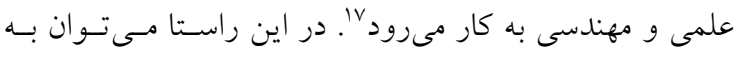

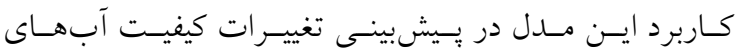

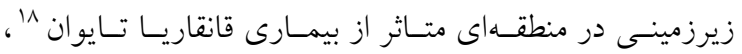
شناسايى منابع آلودگى نامشخص آب زيرزمينى 19 ، شناسـايى منابع غيرقابل دسترس آلودگى آبهاى زيرزمينى با استفاده از

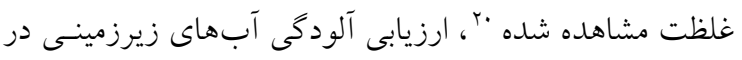

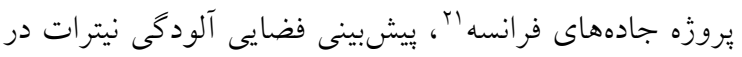

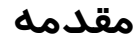

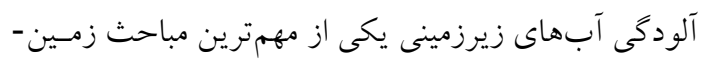

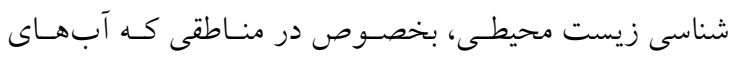

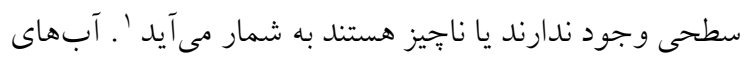

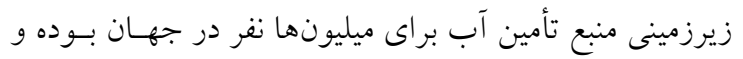

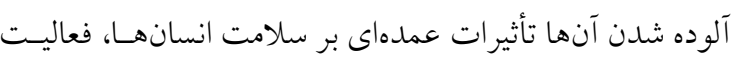

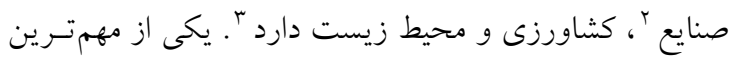

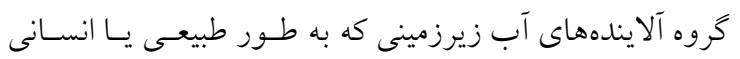
باعث آلودكى آن مىشود، عناصر جزئي و كمياب سمى هستند.

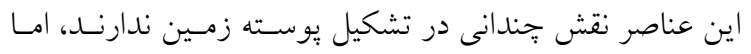

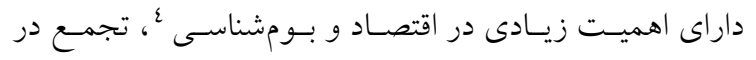

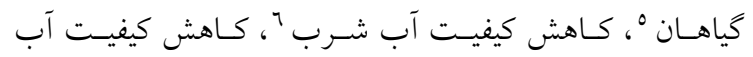

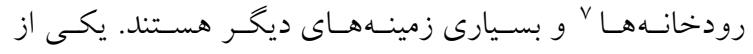

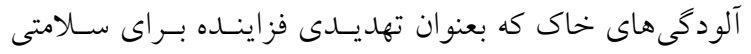

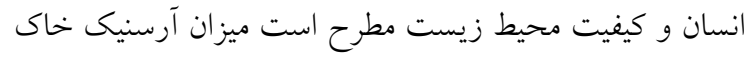

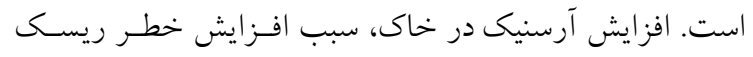

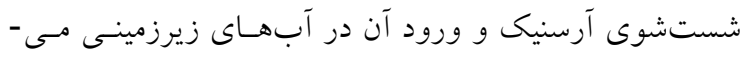
شود ^. وجود مواد مادرى داراى تشكيلات آذرين در خـاك و

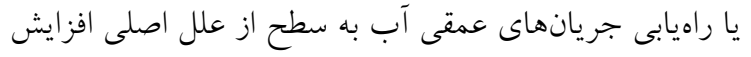

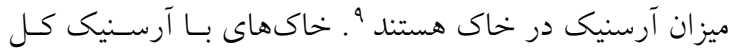

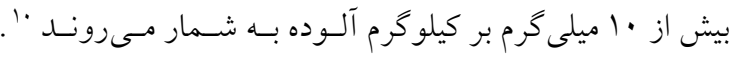

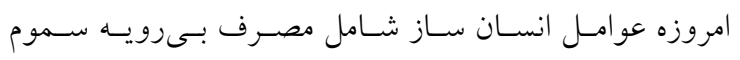

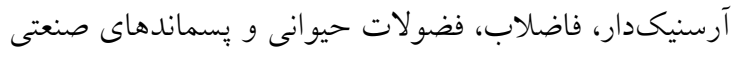

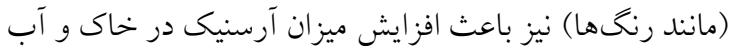

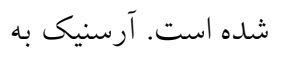

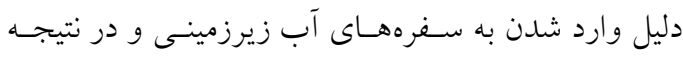

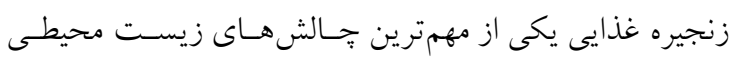

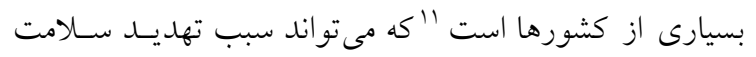


برآورد يتانسيل آلودكى آرسنيك آبهاى زيرزمينى شهرستان سنتدج با استفاده از مدل شبكه عصبى مصنوعى

هانگ و همكاران بَ در بررسـى رابطسهى آلـودگى نيتـرات

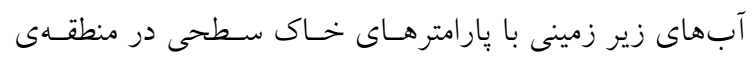

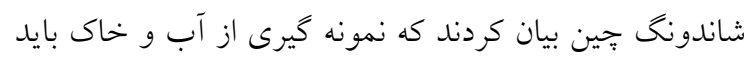
در خاكهاى داراى ساختار مختلف زمين شناسى و با براكنش مناسب در سطح منطقه باشد.

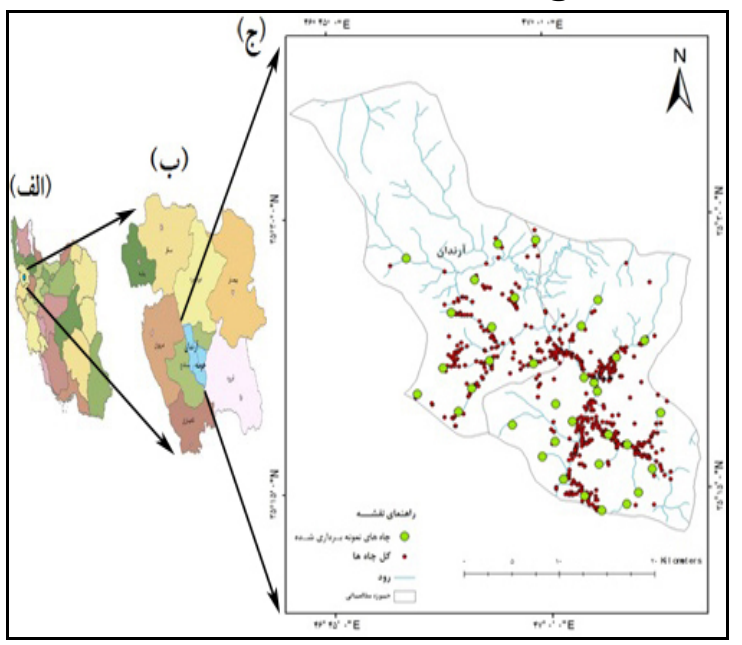

شكل ا: (الف) كشور ايران، (ب) استان كردستان، (ج) نقاط نمونه بردارى

در حوزه مطالعاتى

همجنين بيان داشتند كه تعداد نمونههـا بسـتكى بـه تنـوع ساختار زمين شناسى منطقه خواهد داشت. لذا در اين مطالعـه نيز نقشه جاههاى كم عمق و نيمه عميق در منطقه مورد مطالعه

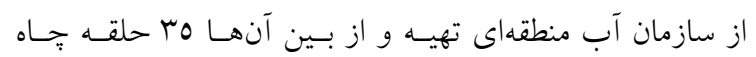

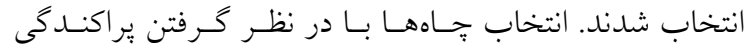
مناسب (فواصل جاهها از يكديخر) و دسترسى به جاهها (جاده اسفالت يا خاكى) (شكل ا-ج) و ساختارهاى مختلف زمسينشناسى (شكل r ) صورت گرفت

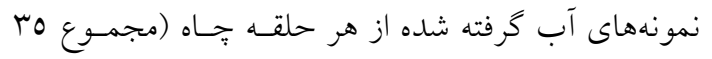

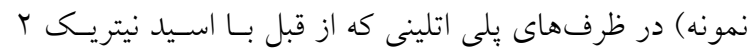

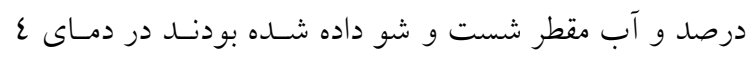
درجه سانتى گراد به آزمايشخاه منتقل و بــا اسـتفاده از دستـاه
آبهاى زيرزمينى بَ، تحليل فضايى الكوى يـراكنش آلـودگى نيترات نيتروزن آبهاى زيرزمينى در مناطق كشاورزى فشـرده

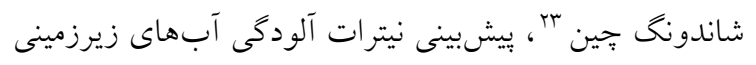
در مناطق روستايى و كشـاورزى نـوار غـزهوعَ اشـاره كـرد. در داخل كشور نيز در رابطه با كاربرد اين مدل مىتوان مدلسازى

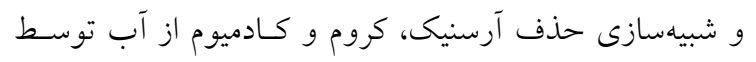
فرايند نانو فيلتراسيون ب0، و شبيهسازى شورى آب زيرزمينى را نام برد. در ايران وجود خاكهاى آلوده به آرسنيك در استان

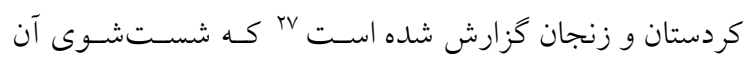
مى -تواند سبب آلوده شدن آب هاى زيرزمينى ايسن منـاطق بـهـ

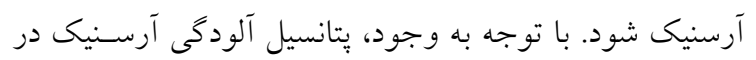

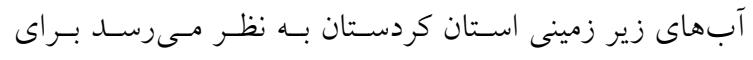

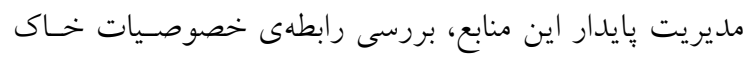

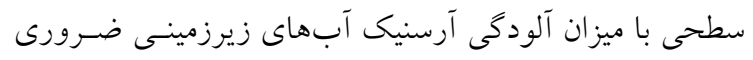
باشد. در اين راستا استفاده از مدلهـاى مختلـف و مقايسـهى

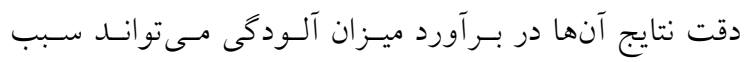
انتخاب مدل بهينه و به تبع آن افزايش دقت برآورد كردد. لـذا لـا هدف اصلى اين مقاله مقايسهى دقت مدلهاى شبكهى عصبى مصنوعى و ركرسيون خطى جنــ گانـه در بـر آورد يتانسـيل آلودكى آرسنيك در آبهاى زيرزمينى شهرستان سنندج است.

\section{مواد و روشها \\ منطقه مورد مطالعه}

شهرستان سنندج، مركز استان كردستان با مساحت MNA/7 هكتار و ارتفاع · ..1 متر از سطح دريا با مختصات جغرافيايى

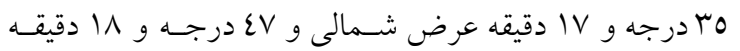
طول شرقى در غرب ايران و در بخش جنوبى استان كردستان قرار دارد شكل ( ا-الف و ب).

نمونهبردارى آب زيرزمينى و خاك 
سامان مرادى و همكاران

شكل r: نقشه جاههاى انتخاب شده بر اساس ساختار زمين شناختى

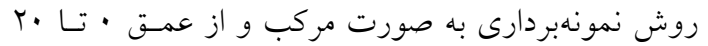

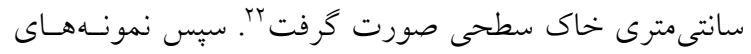

خاى در ياكتهاى كاغذى ريخته شد و با زدن بر جسبـهـايى كه مشخصات جغر افيايى (x,y)، شماره ايستخاه جاههـا و اســم

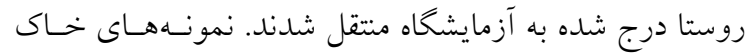
نيز يس از انتقال به آزمايشگاه مورد آناليز قرار گرفتند و ميزان قطر ذرات خاك، ماده آلى، فسفر قابل جـــب، نيتـرات خــاك، ظرفيت تبادل كاتيونى (CEC)، آرسنيك و آرسنيت، اكسيدهاى آزاد آهن و منخنز كل، و اكسيدهاى آزاد آهن و منخنز بىشكل

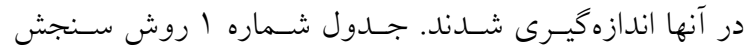
يارامترهاى مورد ذكر را نشان مى دهد.
جذب اتمسى (Biotech مـدلPHOENI986 محصـول كشـور انخلستان) ميزان آرسنيك آب اندازهگيرى گرديد.

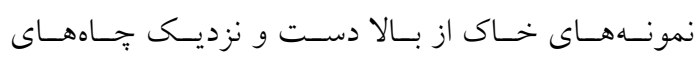
نمونهبردارى شده (0م حلقه جاه ) برداشت شدند.

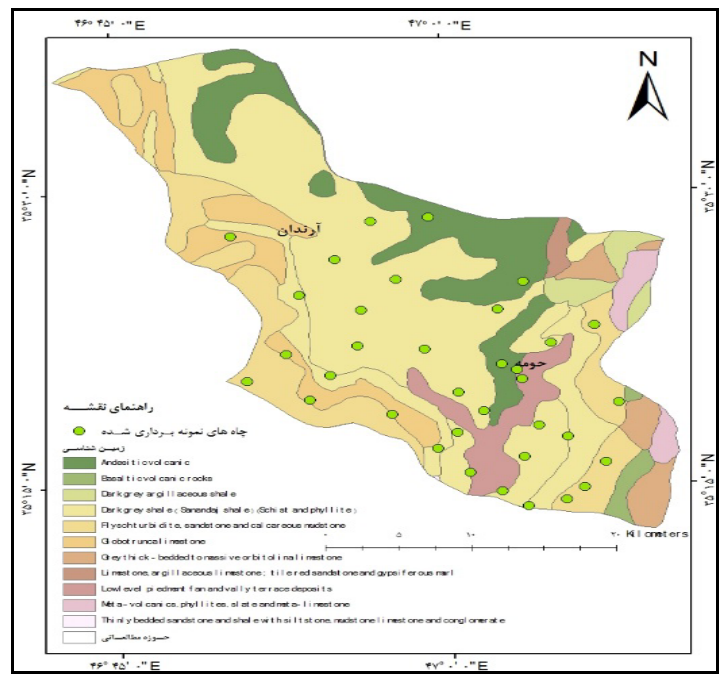

\begin{tabular}{|c|c|c|}
\hline شماره استاندارد & روش سنجش & خصوصيات فيزيكى و شيميايى \\
\hline ro.. & 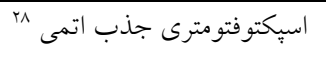 & آرسنيك آب \\
\hline ro.. & اسيكتوفتومترى جذب اتمى جa & آرسنيك خاك \\
\hline ro.. & كسر آرسنيت ازآرسنيك & آرسنات \\
\hline ro.. & اسبكتوفتومترى جذب اتمى ^^ & 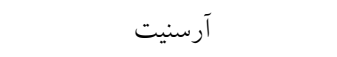 \\
\hline$\varepsilon 1$. & اولسن "، دستخاه اسيكتوفتومتر & 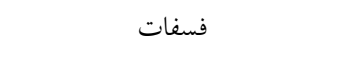 \\
\hline$\varepsilon 1$. & اسِكتوفتو متر & 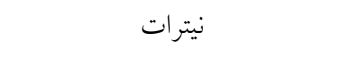 \\
\hline rmo. & و الكى بلك & 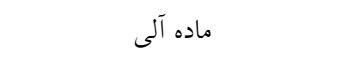 \\
\hline rmo. & 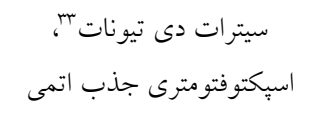 & منغنز كل \\
\hline rmo. & 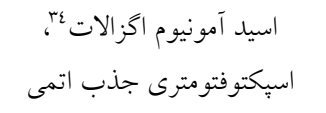 & منكخز بى شكل \\
\hline rmo. & 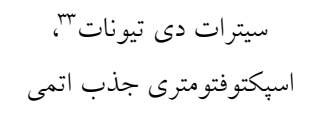 & 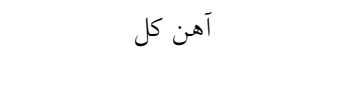 \\
\hline rmo. & 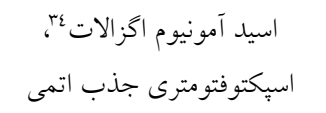 & آهن بى شكل \\
\hline rol. & استات سديم، فلم فتومتر ro & ظرفيت تبادل كاتيونى \\
\hline 1. vo. & روش هيدرومترى r7 & سيلت \\
\hline
\end{tabular}




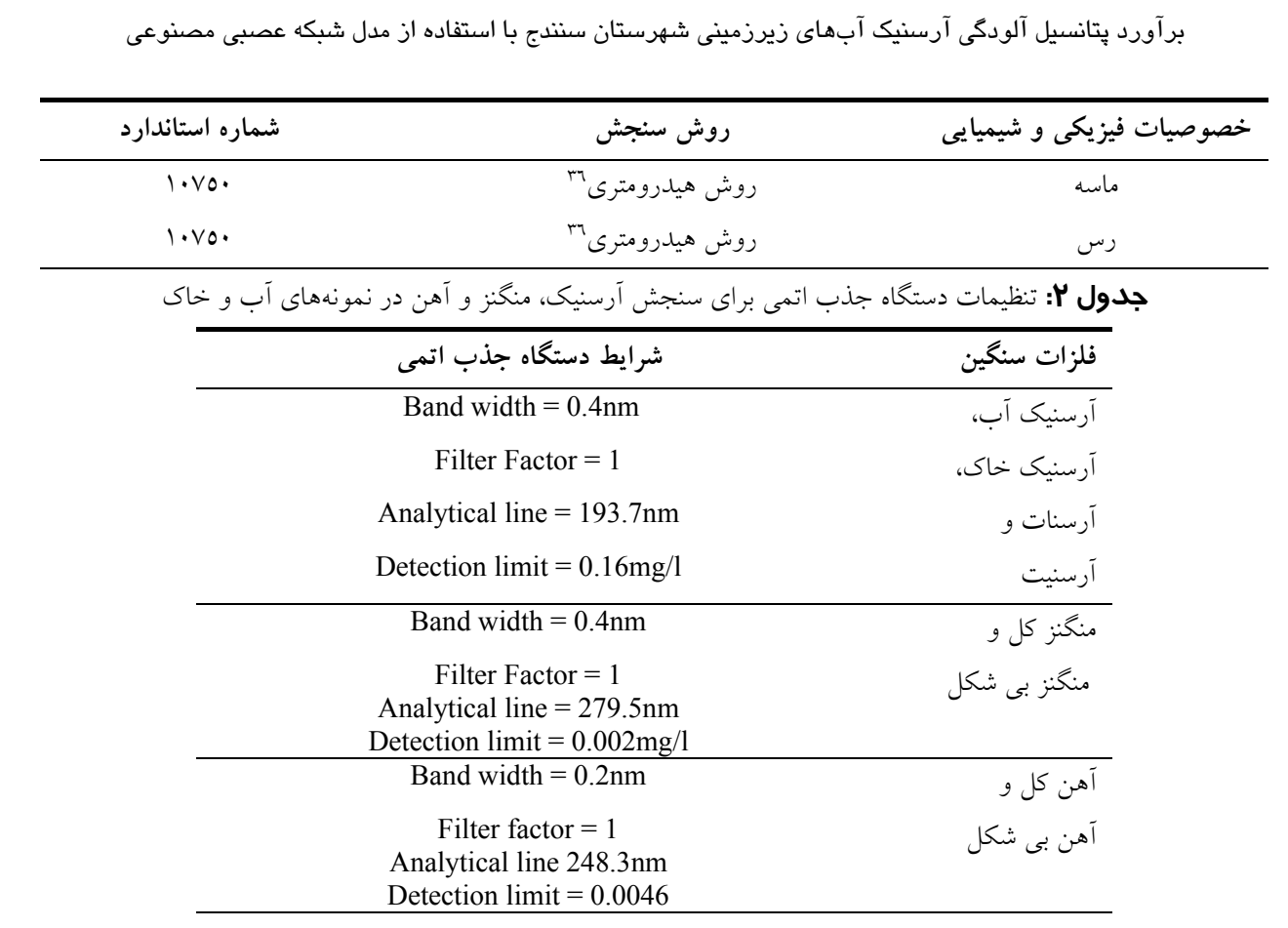

عدم اغتشاشات بستخى دارد، جِرا كه ايسن روشهــا در مقابـل

اطلاعــات نادرسـت حساسـيت بـالايى داشـته ورود جنــين

دادههايى منجر به بــروز خطاهـاى بـزرگ و فـاحش در نتـايج مىشود. بهترين كارايى اين روش در برابر متغيرهاى با توزيـع

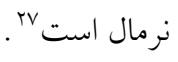

\section{نرمالسازى دادمها}

ابتــدا تبعيـت دادههـا از توزيـع نرمـال بـهـ وسـيله آزمسون

كولموكروف اسميرونوف بررسى شد. نظـر بـه نرمـال نبـودن توزيع، جهت نرمال نمودن دادهها از رابطهى (1) استفاده شـد. نكته قابل توجه در آموزش شبكههاى عصبى مصنوعى قبـل از

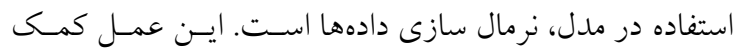
شايانى به آموزش بهتر و سريعتر مدل مى كند. وارد كردن دادهها به صورت خام باعث كاهش دقت و سرعت در شبكه مسى -

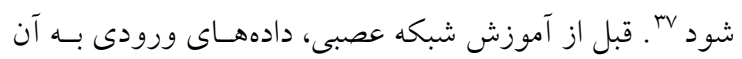

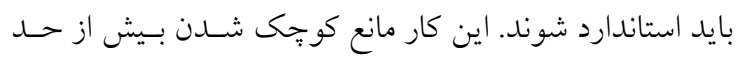

تنظيمات دستخاه جذب اتمى براى سنجش آرسنيك شامل

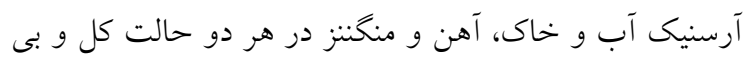
شكل در جدول شماره r نشان داده شده است

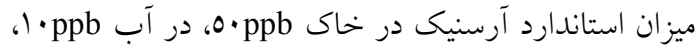

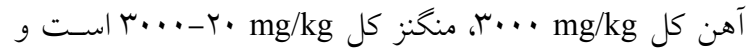
بهترين غلضت نيترات خاى كـهـ در آن گياهـان بلاتـرين حـــ

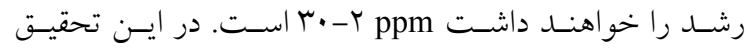
رابطهى بين ميزان آرسنيك اندازهيرى شده در نمونههاى آب

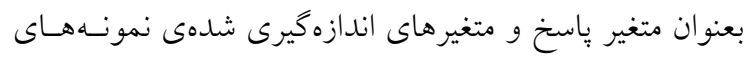

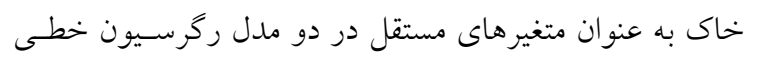
جند كانه و شبكه عصبى مصنوعى مورد آزمون قرار كرفتند.

\section{رَرسيون خطى حند گَانه تك عاملى}

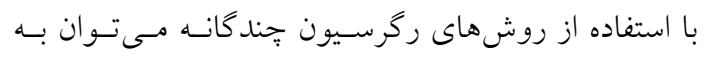

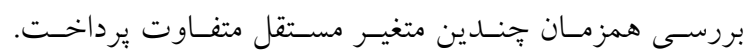
عملكرد مناسب اين روش تا حد زيادى بـه صسحت دادههـا و 


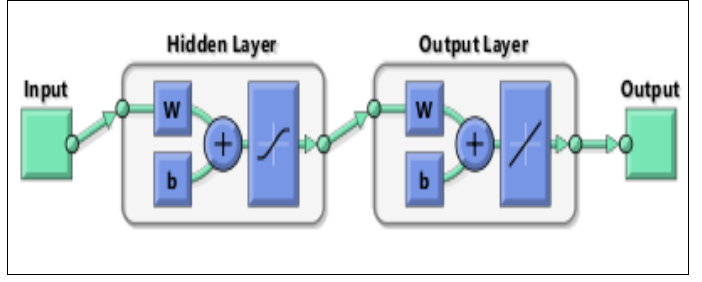

شكل سا: ساختار شبكه عصبى مصنوعى

درونيابى

امروزه بصورت وسيعى از روشهــاى متــاول درونيـابى

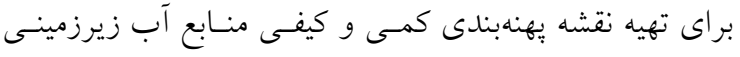

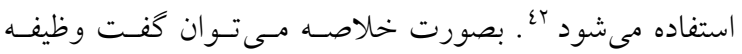
درونيابى آن است كه به بررسى آن دسته از متغيرها مى يردازد

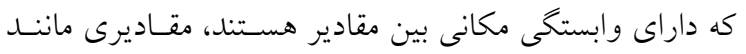

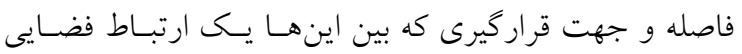

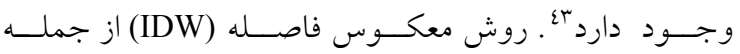

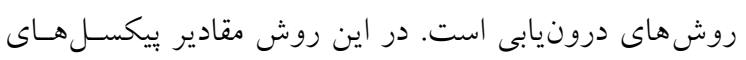

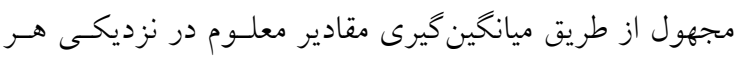

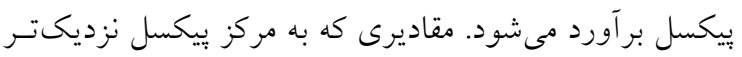

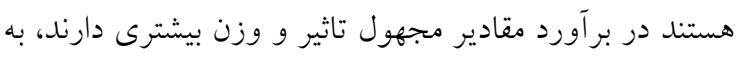

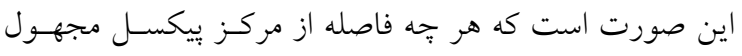

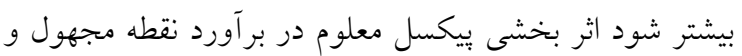

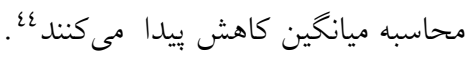

\section{يافتهها}

سازمان بهداشت جهانى (WHO) و آرَانس حفاظت محيط

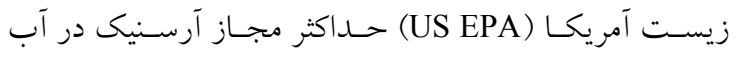

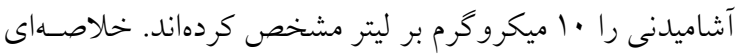

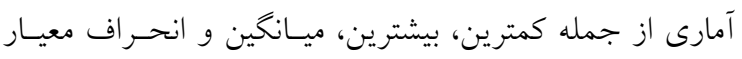

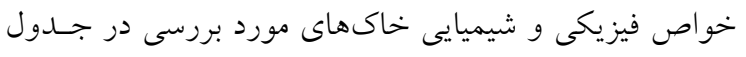

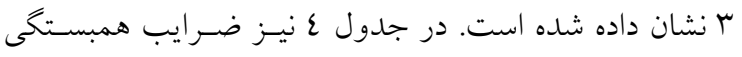

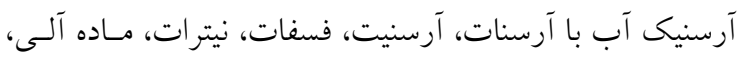

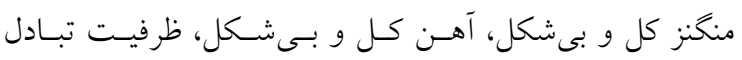

وزنها مى شود. براى نرمال سازى دادهها از رابطه ( (1) اسـتفاده شد ش ${ }^{\mu}$ $\mathrm{Xn}=(\mathrm{X}-\mathrm{Xmin}) /(\mathrm{Xmax}-\mathrm{Xmin})$

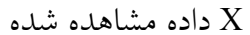
حداكثر داده مشاهده شده Xmax Xmin شبكه عصبى مصنوعى شبكه عصبى مصنوعى نوعى سـامانهى يــردازش اطلاعـات است كه عملكردى شبيه شبكه عصبى زيست شـناختى داردج" . هر شبكهى عصبى مصنوعى از سه لايــه اصـلى ورودى، ينهـان (مخفى) و خروجى تشكيل شده است. در هر لايه جنــد عنصـر يردازشخر (نرون) وجود دارد، كه بـه نـرونهـاى لايـه مجـاور متصل هستند. واحسـدهاى لايـه ورودى وظيفـه توزيـع مقـادير ورودىها به لايه بعد و لايه خروجى نيز پاسـخ سـيخنالهـاى خروجى را ارائه مىدهد. در اين دو لايه، تعداد نرونها برابر بـا تعداد ورودىها و خروجىىها مىباشد و لايه يا لايههاى ينهان وظيفه ارتباط لايههاى ورودى به لايههاى خروجى و به دسـت آوردن روابـط خطى و غيرخطى بـين متغيرهـا را بـر عهـده دارند •ع. در يك مدل شبكه عصبى اين كه وزنهـاى موجـود در شبكه عصبى به نحو مطلوبى بــــآورد شـوند حسائز اهميـت

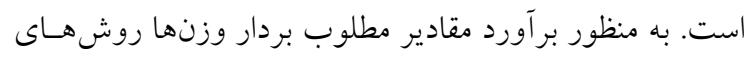
متعددى استفاده مىشود كه مهمترين و يركاربردترين آنهـا در شبكه عصبى برسترون تجند لايه مورد استفاده قرار مسى گيـرد.

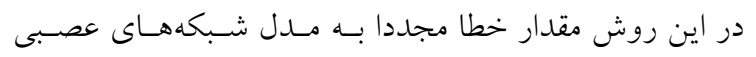
منتقل و مقادير وزنها را تعديل مىنمايد اع. در ايسن بــزوهش روس براى طراحى شبكه عصبى يُرسيترون جّند لايه از جعبـه ابـزار

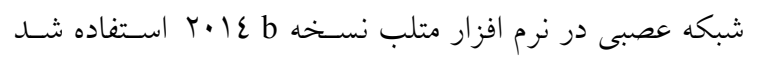
(شكل ؟). مدل استفاده شده در شبكه عصبى يسس از آزمـون و

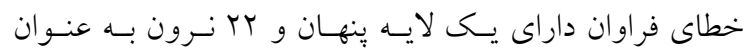
مناسبترين مدل بوده است. الكوريتم آموزشى از نوع لونبرى

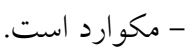


برآورد يتانسيل آلودكى آرسنيك آبهاى زيرزمينى شهرستان سنتدج با استفاده از مدل شبكه عصبى مصنوعى

كاتيونى، رس خاك و سيلت خاك نشان داده شده اسـت. بـر استاندارد آلودگى و در اكثر ايستخاهها كمتر از آستانه استاندارد

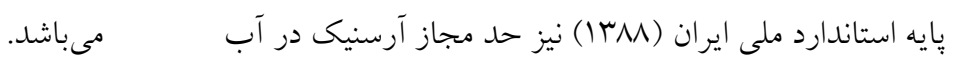

آشاميدنى ·ل ميكروخرم بر ليتر است. مقدار آلـودگى آرسـنيكى

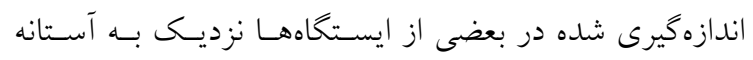

جدول سا: مقادير اندازهيرى شده ويزگى هاى فيزيكى و شيميايى خاكهاى مورد مطالعه

\begin{tabular}{|c|c|c|c|c|}
\hline انحر اف معيار & ميانخين & بيشترين & 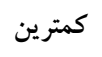 & خصوصيات فيزيكى و شيميايى \\
\hline.$/ T I Y$ & $0 / r$ & $9 / 7$ & $r / \varepsilon$ & آرسنيك آب \\
\hline$\cdot / 479$ & $\varepsilon / V$ & $11 / 1$ & $\cdot / \mathrm{VV}$ & آرسنيك خاى \\
\hline . TrEY & וTM & 200 & Trt & آرسنات \\
\hline . $/ 477$ & $\varepsilon / \varepsilon$ & $1 \cdot / 1$ & $\cdot / 20$ & آرسنيت \\
\hline$\cdot / I V A$ & $9 / 1$ & $10 / 9 \varepsilon$ & $T / V$ & فسفات \\
\hline . / rrר &.$/ 770$ & $\cdot / v \varepsilon 0$ & $\cdot / 291$ & 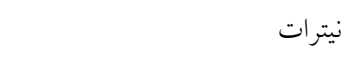 \\
\hline$\cdot / r \cdot r$ & $r / r)$ & $\varepsilon / 94$ & $\cdot / \mu \varepsilon$ & 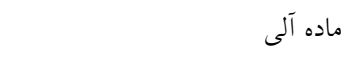 \\
\hline$\cdot / Y I r$ &.$/ 1 V I$ & $\cdot / r O \Lambda$ & $\cdot / 11 \%$ & منكنز كل \\
\hline.$/ 19 \varepsilon$ & $\cdot / \cdot \varepsilon$ & $.1 \cdot 91$ & $\cdot$ & منكنز بى شكل \\
\hline ת & $1 / 79$ & $r / r \varepsilon$ & $\cdot / 9 V$ & آهن كل \\
\hline.$/ Y I 1$ & $\cdot / 207$ & $\cdot / 9 \mathrm{~V}$ &.$/ 410$ & آهن بى شكل \\
\hline . & $07 / 7$ & $7 \cdot / \wedge \varepsilon$ & $0.1 \cdot r$ & ظرفيت تبادل كاتيونى \\
\hline . & TN/TQ & $\{\varepsilon / 0\}$ & $q / \wedge \varepsilon$ & سيلت \\
\hline . MTE & $0 . / 9 \varepsilon$ & $\Lambda \varepsilon / N Y$ & TN/AM & ماسه \\
\hline$\cdot / r \cdot \Lambda$ & $T \cdot / V T$ & rV/rA & $0 / Y A$ & رس \\
\hline
\end{tabular}

\begin{tabular}{|c|c|c|c|}
\hline آزمون t & انحراف استاندارد & ضرايب & متغيرهاى مستقل \\
\hline$-1 / \pi 91$ &.$/ 19$ & $-\cdot / T \varepsilon V$ & $\mathrm{As}(\mathrm{III})$ \\
\hline$\cdot / V \varepsilon V$ & $\cdot / \mu_{\Lambda}$ & $\cdot / 1 \cdot r$ & $\operatorname{As}(\mathrm{V})$ \\
\hline$-1 / 007$ & $\cdot / 470$ & $-\cdot / \varepsilon \mid r$ & $\mathrm{PO}_{4}^{-2}$ \\
\hline.$/ 479$ & $\cdot / \backslash \Lambda \mid$ & $\cdot / \cdot \varepsilon q$ & $\mathrm{NO}_{2}$ \\
\hline$r / 199$ & ו ו ו & $\cdot 10 \cdot 1$ & $\mathrm{OM}$ \\
\hline.$/ 01 r$ & . ror &.$/ 1 r q$ & $\mathrm{Mn}_{\mathrm{d}}$ \\
\hline$-\cdot$ - VAN & . & - & $\mathrm{Mn}_{\mathrm{o}}$ \\
\hline$-1 / r 71$ &.$/ 190$ & $-\cdot / r \varepsilon V$ & $\mathrm{Fe}_{\mathrm{d}}$ \\
\hline$-\cdot / \Lambda \mid \Lambda$ & $\cdot / T \wedge \varepsilon$ & - & $\mathrm{Fe}_{o}$ \\
\hline$-1 / 7 \vee \varepsilon$ & - TYE & $-\cdot /$ rVo & CEC \\
\hline
\end{tabular}




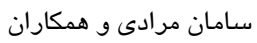

\begin{tabular}{|c|c|c|c|}
\hline$-\cdot / 1 \varepsilon 7$ & $\cdot / r 7 \varepsilon$ & $-.0 . r q$ & Silt \\
\hline $1 / \pi q \varepsilon$ & $\cdot / \varepsilon / r$ & $\cdot / \Gamma 7 \varepsilon$ & Clay \\
\hline & 政 & $\cdot / 011$ & Constant* \\
\hline
\end{tabular}

ضريب ثابت در فرمول ركرسيونى مى باشد. : Constant*

\section{نتايج حاصل از شبكه عصبى مصنوعى}

مدلهاى شبكه عصبى مصنوعى جهت طر احى نيازمند سه دسته

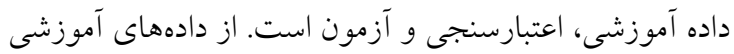

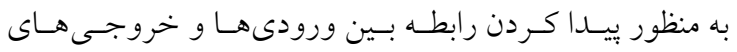
مشاهدهاى استفاده مى گردد، از دادههاى اعتبارسنجى به منظـور

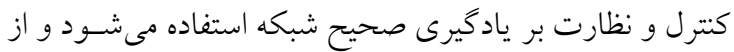
دادههاى آزمون براى ارزيابى عملكرد شبكه بيشنهادى استفاده مى كردد.

در اين يزووهش • V درصد كل دادههـا، بـراى آمـوزش، 10 درصد اعتبارسنجى و 10 درصد آزمون مدل اختصـاص يافتـ.

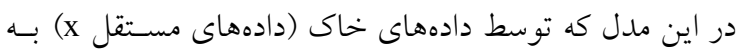

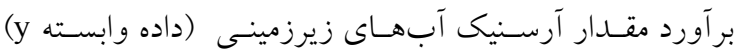

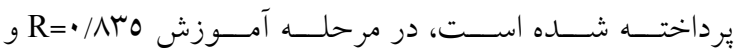
MAE=•/111 و RMSE=•/1 107 مقــير RMSE=•/IVV و R R R

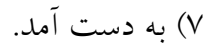

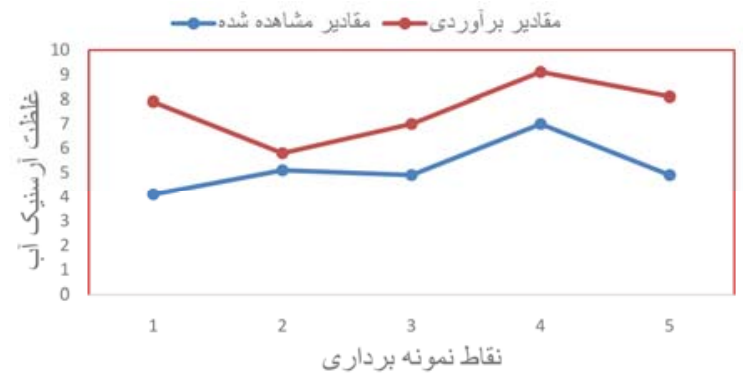

شكل ه: نمودار نتايج حاصل از شبيهسازى آرسنيك آبهاى زيرزمينى در

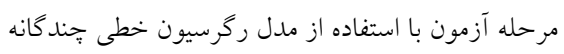

غلظت آلودكى آرسنيك در خاى تحت تاثير عوامل زيادى مى باشد كه مى تــوان بـهـ ايسن مـوارد اشـاره كـرد: كلوئيسـهاى

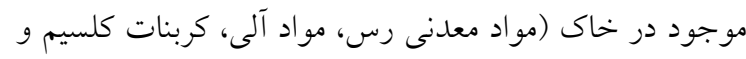

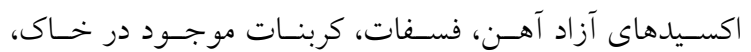

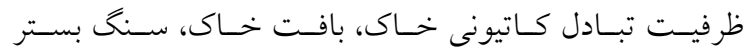

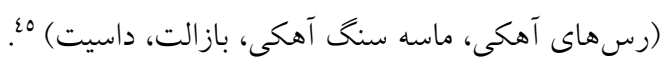

\section{نتايج استفاده از آناليز ركرسيون خطى حند گَانه}

در اين مدل كه توسط دادهاى خاك (دادههاى مستقل x)

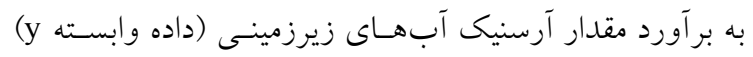

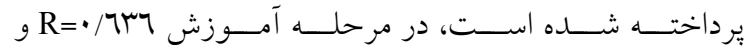
و RMSE=•/100 آزمسون مقــادير RME به دست آمد (شكل 0).

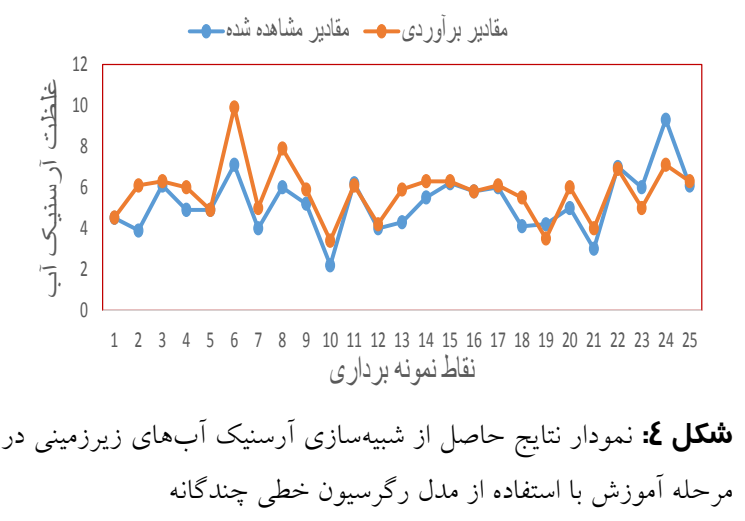


برآورد يتانسيل آلودكى آرسنيك آبهاى زيرزمينى شهرستان سنتدج با استفاده از مدل شبكه عصبى مصنوعى

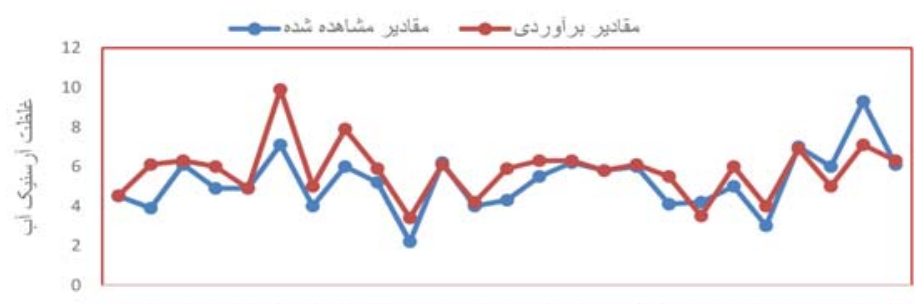

$\begin{array}{lllllllllllllllllllllllll}1 & 2 & 3 & 4 & 5 & 6 & 7 & 8 & 9 & 10 & 11 & 12 & 13 & 14 & 15 & 16 & 17 & 18 & 19 & 20 & 21 & 22 & 23 & 24 & 25\end{array}$ نقاط نسوند برد دارى

شكل \&: نمودار نتايج حاصل از شبيهسازى آرسنيك آبهاى زيرزمينى در مرحله آموزش با استفاده از مدل شبكه عصبى مصنوعى بردى

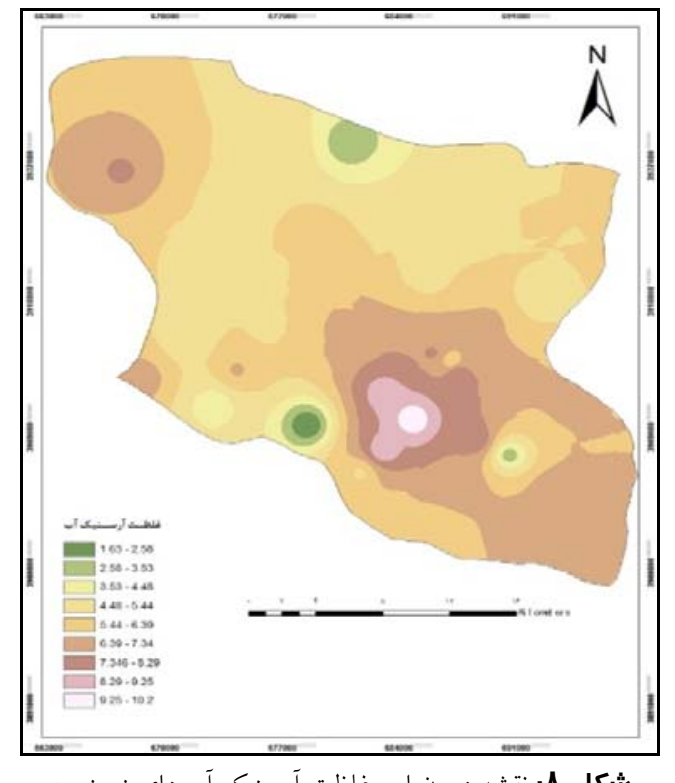

شكل A: نقشه درونيابى غلظت آرسنيك آبهاى زيرزمين

\section{بحث}

\section{تغييرات آلودگى آرسنيك در آبهاى زيرزمينى}

معيار كيفيت خاك توسط سازمان حفاظت محسيط زيست

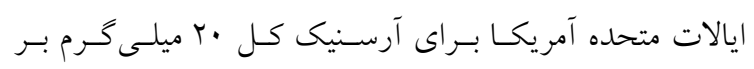

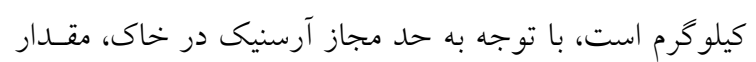

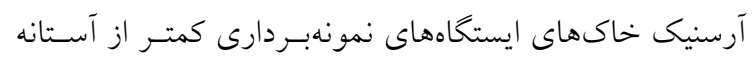

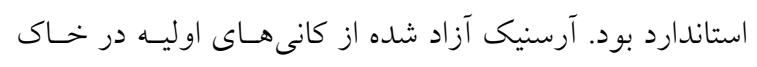

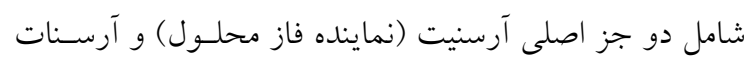

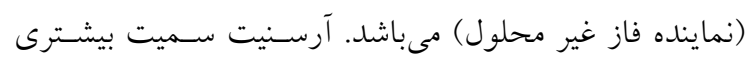

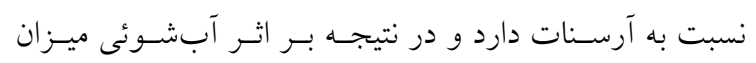

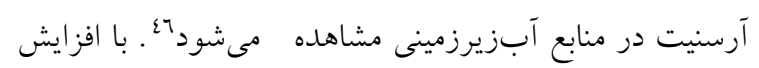

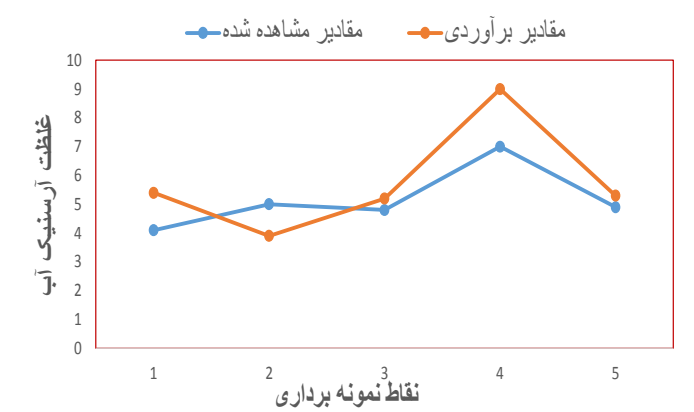

شكل V: نمودار نتايج حاصل از شبيهسازى آرسنيك آبهاى زيرزمينى در

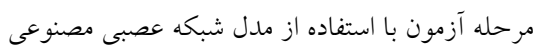

\section{نتايج حاصل از درونيابى}

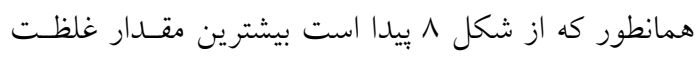

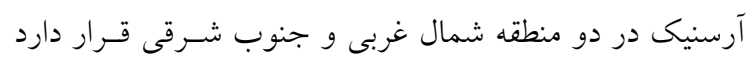

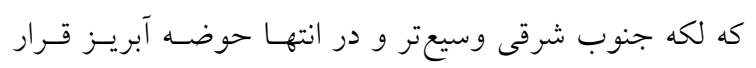

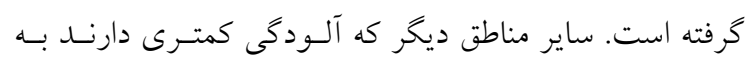

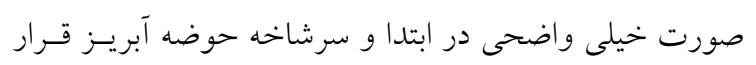

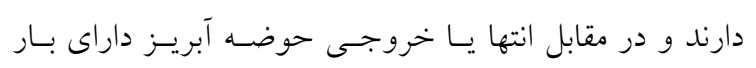
غلظت بيشترى از آلودگى آرسنيك است. 
ظرفيت تبادل كاتيونى خاك افزايش يافته و به طبـع آن جـــب

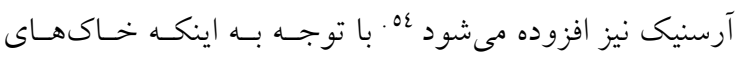

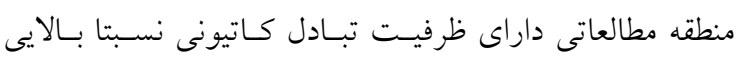
مىباشد تثبيت آرسنيك توسط ظرفيت تبـادل كـاتيونى خـاى افزايش بيدا مى كند كه اين امر نيز مىتواند يكى از دلايل كمتر

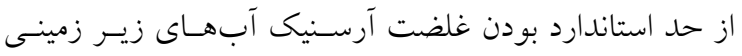
منطقه باشد. توزيع آرسنيك معمولا در بافت خاك تحت تـأثير ساير ذرات متفاوت است. سميت آرسنيك در خاكهاى بسيار ريز كمتر است جون تحرى آرسنيك در اين خـاكهـا تحــت تأثير اكسيدهاى آهن قرار دراده. به طور كلى سطوح اكسـيدها در حاشيه ذرات شكسته شده رسهاى يـايين داراى در مر مثبت باردار هستند بنابراين باعث جذب آنيـونهـا و بـهـ ويـزّه آرسنات مىشوند ${ }^{0}$. بيشترين تثبيت آرسنيك به شكل آرسنات در خاكهاى با محتو اي رس و سيلت به وقـوع مسى يبيونـدد. بـاــا توجه به اينكه خاكهاى منطقه مطالعاتى داراى بافت متوسطى

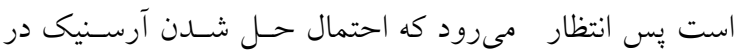
خاى وجود داشته باشد و به آب زيرزمينى راه يابد. با توجه به

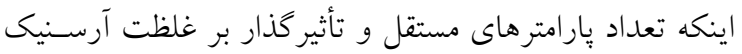
خاى مورد مطالعه نسبتا زياد است و يارامترهاى مانند فسفات و نيترات در غلظـتهــاى متفـاوت داراى رفتارهـاى مختلفى است و همجنين اثـــ كاهشى ظرفيـت تبـادل كـاتيونى و اثـر افزايشى بافت خاك بر حل شدن آرسنيك خاك و بـهـ تبـع آن ورود آن به سفرههاى آب زيرزمينى منطقه، لـذا نمسى تـوان بـــ

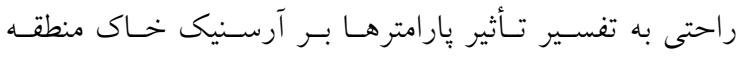
يرداخت و به همـين دليـل اسـت كـه از مــل شـبكه عصـبى مصنوعى براى ييدا كردن روابط بيّيجيده غيرخطى استفاده شده

\section{مقايسه و ارزيابى مدل رَرسيون خطى خندكَانـهـ تك عاملى با مدل شبكه عصبى مصنوعى}

يافتهاى يزّوهش حاضر برتر بودن مدل شـبكه عصسبى را
ميزان سهم آرسنيت مخاطرات زيستمحيطى آرسنيك از جمله آبشوئى و آلودكى منابع آبى افزايش بيدا مى كند در حاليكه با

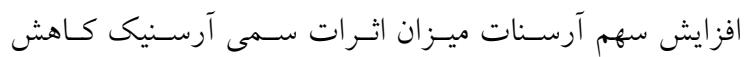
مى يابد VI . تثبيت آرسنيك در خاك با ترغيب تشكيل آرسنات آرسي همراه است كه تحرى و آبشوئى آرسـيكى را كـاهش مسى -

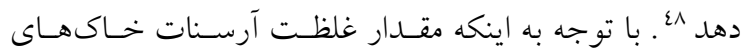

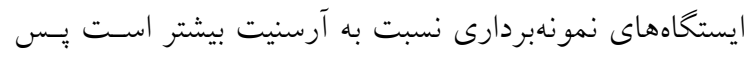

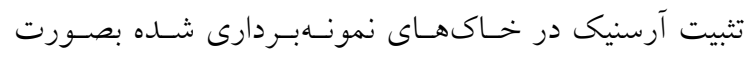
آرسنات است و نخر انى در مـورد مخـاطرات زيسـتمحيطى لَّى آرسنيك از جمله آبشوئى و آلودگى منابع آبى كم مىشود كه

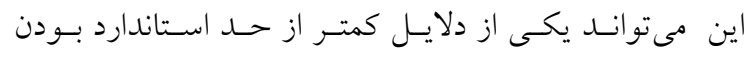
غلضت آرسنيك آبهاى زير زمينى منطقه باشد. آرسـنيك بـا غلبه بر نيروى جاذبه بين يونهاى فسفات جذب شده در سطح كلوئيدهاى خاى مىتواند جايخزين فسفات شود. امـا افـزايش بيشتر در ميزان فسفات منجر به معكوس شدن اين فرآيند شده و باعث واجذب آرسنات مىشود "هء. آرسنات با غلبه بر نيروى جاذبه ميان يونهاى نيترات جذب شـده در سـطح كلوئيـدهاى داراى بار مثبت در خاى از جمله اكسيدهاى آزاد آهن جايخزين

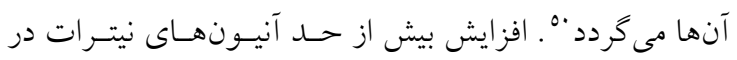

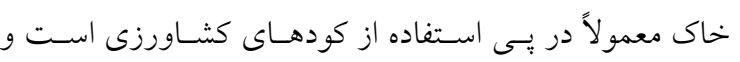
باعث آزاد شدن آرسنات از سطح كلوئيـدها بـه درون محلـول

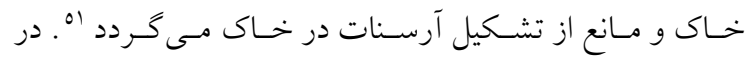
هاى بالا N/0 تا 9/0 اتصال آرسـنيك بـا اكسـيدهاى آهـن ضعيفتر از هاى بايينتر اسـت و بنـابراين باعـث آلـودگى بيشترى مى شود مُ . بيشينه جذب آرسـنات توسـط اكسـيدهاى

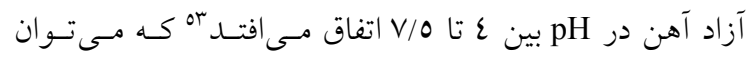
نتيحه كرفت با توجه به دامنه pH خـاكهـاى منطقـه (V/0 تـا

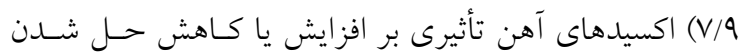
آرسنيك خاك در منطقه مطالعاتى نداشتهانـد. ظرفيـت تبـادل كاتيونى خاى تحت تأثير ذرات رس، مـاده آلى و اكسـيدهاى آزاد آهن قرار دارد. لذا انتظار مىرود كه با حضور ايسن عوامـل 
نتايج دقيقترى است. برترى شبكه عصبى نسبت به ركرسيون

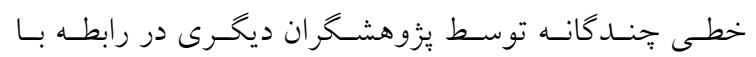
مطالعات آب زير زمينى ثابت شده است و با نتايج اين مطالعه نوسن

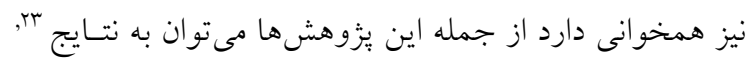

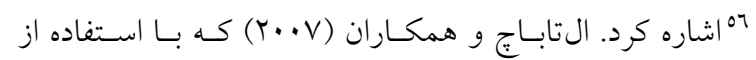

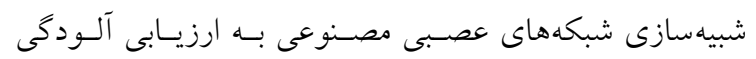

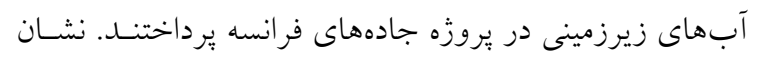

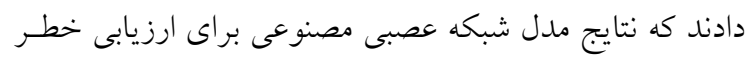

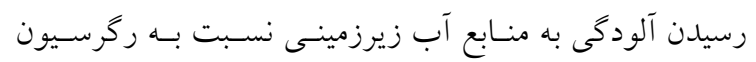

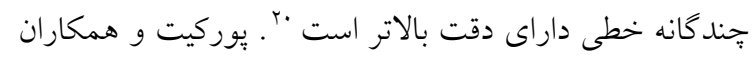
نيز (Y..人)

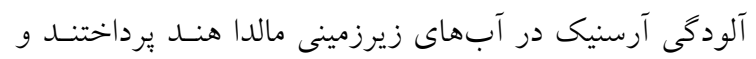

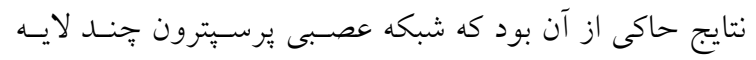

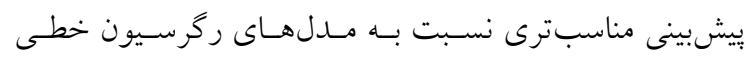

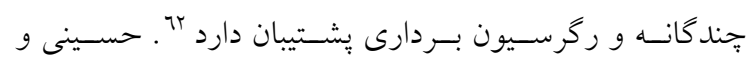

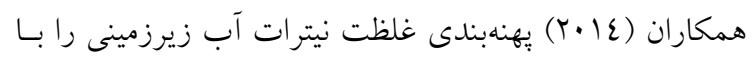

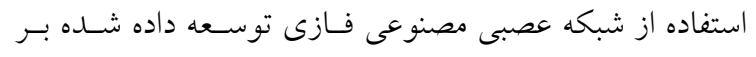

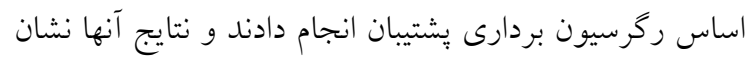

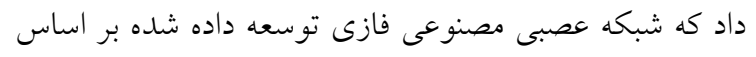

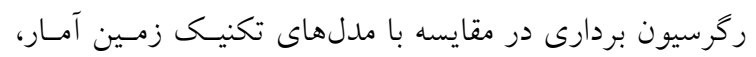
خطى، درجه دوم، جّند جملهاى و توابع هسته كاوسى عملكرد بهترى دارد "ج.

بررسى تغييرات مكـانى آرســيكـ بـا اسـتفاده از عمليات درونيابى دئى بيشترين مقدار غلظت آرسنيك در شمال غربس و جنسي شرقى منطقه مطالعاتى است كه لكه جنوب شرقى وسـيع تـر و

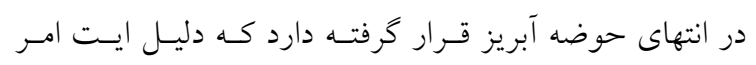

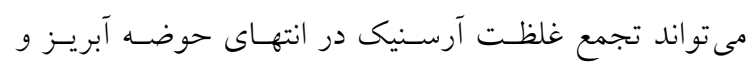

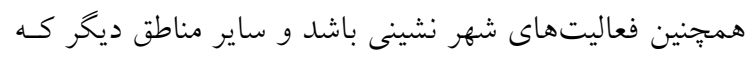
آلودكى كمترى دارند به صسورت خيلسى واضسحى در ابتــدا و

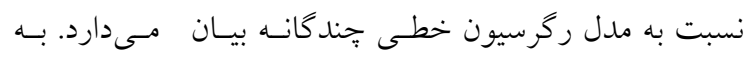
طورى كه استفاده از شـبكه عصسبى مصـنوعى صـحت نتسيج

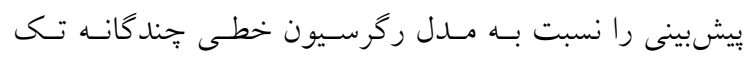

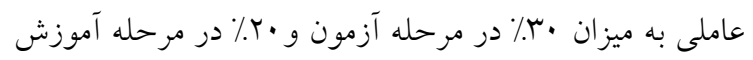

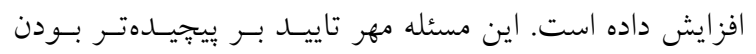

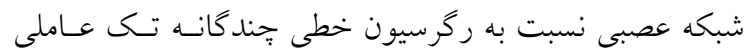

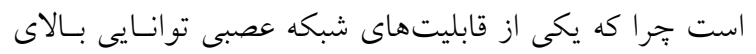

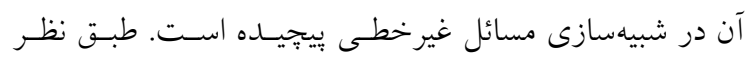

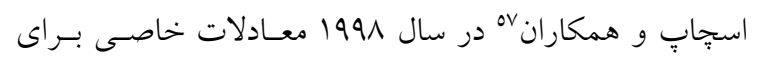

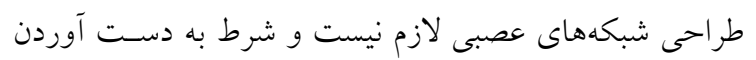
نتيجهى دقيق ايجـاد رابطـه مناسـب بـين دادهــاى ورودى و و خروجى است. اين امر زمانى بيشتر نمود بيدا مى كند كه دادهها

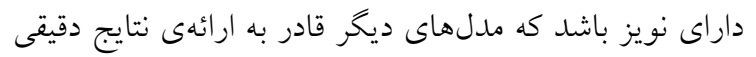
نيستند ولى مدل شبكه عصبى به دليـل قابليـت تعمسيم بسـيار

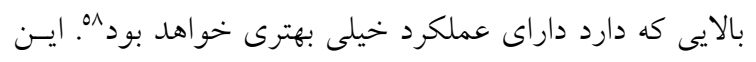

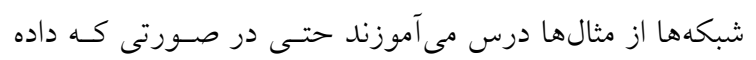
كافى وجـود نداشـته باشـــ ايـن مــل روابـط بـين داده رادر صورت ناشناخته بودن روابط يا دشوار بـودن توصسيف آنهــا،

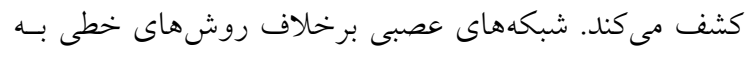

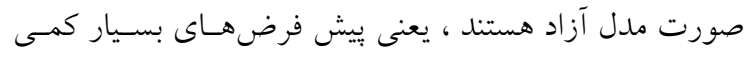
دارند.. حساس نبودن اين شبكه به وجود تعداد محدودى خطا

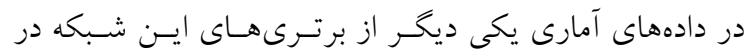
مقايسه با مدلهاى خطى است. تنها محدوديت اين شبكهها در غير قابل تفسير بودن نتايج حاصل از مدلسازى از نظـر ميـزان

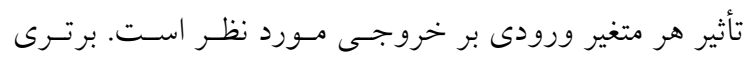

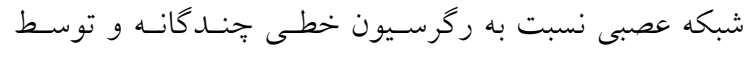

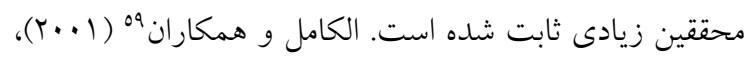

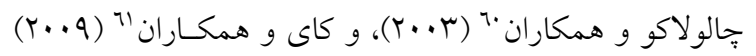

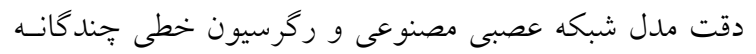

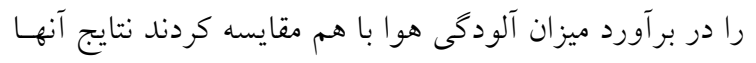

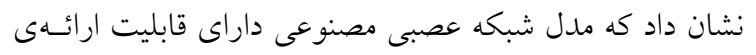




$$
\begin{aligned}
& \text { عصبى مصنوعى مىتواند روش مناسبى براى بيــا كـردن ايسن } \\
& \text { روابط بيبجيده و غيرخطى باشد. كه يافتهاى يـزّوهش حاضـر } \\
& \text { نيز برتر بودن مدل شبكه عصبى را نسبت بـه مــدل رگرسـيون } \\
& \text { خطى جند گُانه نشان مى هد. }
\end{aligned}
$$

\section{References}

1. Nazari $M$, Burston $M$, Bishop $P$, Lerner D. Urban Ground-Water Pollution: A Case Study from Coventry, United Kingdom. Ground Water 1993; 31: 417-24.

2. Jousma G, Bear J, Haimes YY, Walter F. Groundwater Contamination: Use of Models in Decision-Making: Proceedings of the International Conference on Groundwater Contamination: Use of Models in DecisionMaking, Amsterdam, The Netherlands, Organized by the International Ground Water Modeling Center (IGWMC), Indianapolis Delft. Sp Sci \& Bu Me 2012: 26-9.

3. Movahhed S, Kalantari RR, Khezri M, Azari A. Deteminig and analyzing corrosion potential of groundwater in Ghorveh through simulating corrosion indices. J Environ Health Eng 2017;4(3): 233-42 [In Persian].

4. Aiuppa A, Federico C, Allard P, et al. Trace metal modeling of groundwater-gas-rock interactions in a volcanic aquifer: Mount Vesuvius, Southern Italy. Chem Gol 2005; 216: 289-311.

5. Mortazavi S, Hatami Manesh M. Determination of heavy metals pollution load index in sediments and aquatic plant (Nasturtium microphyllum) in Bashar river, Yasuj. J Environ Health Eng 2017;5(2): 157-72 [In Persian].

6. Aghalari Z, Jafarian S. Survey of nitrite and nitrate in mineral water available in the city of Babol in 2015. J Environ. Health Eng 2017; 5(1):65-72 [In Persian].

7. Alizadeh M, Mirzaei R, Kia SH. Determining the spatial trend of water quality indices across Kan and Karaj river basins. J Environ Health Eng 2017;4(3): 243-56 [In Persian].

8. Jiang J. Removing arsenic from groundwater for the developing world-a review. Water Sci Technol 2001;44: 89-98.

9. Sisr L, Mihaljevič M, Ettler V, et al. Effect of application of phosphate and organic manure-based fertilizers on arsenic transformation in soil columns. Environ Monit Assess 2007;135: 435-473.

$$
\text { غرشاخه حوضه آبريز قرار دارند. }
$$

10. Adriano DC. Trace elements in terrestrial environments:biogeochemistry, bioavailability, and risks of metals. Spr 2001: 165.

11. Garg N, Singla P. Arsenic toxicity in crop plants: physiological effects and tolerance mechanisms. Environ Chem Lett 2011; 9: 303-321.

12. Chen JC, Chang N, Shieh W. Assessing wastewater reclamation potential by neural network model. Eng Appl Artif Intel 2003; 16: 149-157.

13. Kuzmanovski I, Aleksovska S. Optimization of artificial neural networks for prediction of the unit cell parameters in orthorhombic perovskites; Comparison with multiple linear regression. Chemomet Intell Lab 2003; 67: 167174.

14. Zhou Q, Jiang H, Wang J, et al. A hybridmodel for $\mathrm{PM}_{2.5}$ forecasting based on ensemble empirical mode decomposition and a general regression neural nrtwork. Sci Total Environ 2014; 496: 264-274.

15. Cobourn WG. An enhanced $\mathrm{PM}_{2.5}$ air quality forecast model based on nonlinear regression and back-trajectory concentrations. Atmos Environ 2010; 44: 3015-3023.

16. Kuo JT, Hsieh MH, Lung WS, She N. Using artificial neural network for reservoir eutrophication prediction. Ecol Model 2007; 200: 171-177.

17. Hassan J. ARIMA and regression models for prediction of daily and monthly clearness index. Renew Energy 2014; 68: 421- 427.

18. Kuo YM, Liu CW, Lin KH. Evaluation of the ability of an artificial neural network model to assess the variation of groundwater quality in an area of blackfoot disease in Taiwan. Water Res 2004; 38: 148-158.

19. Singh RM, Datta B. Artificial neural network modeling for identification of unknown pollution sources in groundwater with partially missing concentration observation data. Water Resour Manag 2007; 21: 557572 .

20. El Tabach E, Lancelot L, Shahrour I, Najjar Y. Use of 


$$
\text { برآورد يتانسيل آلودكى آرسنيك آبهاى زيرزمينى شهرستان سنتدج با استفاده از مدل شبكه عصبى مصنوعى }
$$

artificial neural network simulation metamodelling to assess groundwater contamination in a road project. Math Comput Model 2007; 45: 766-776.

21. Gemitzi A, Petalas C, Pisinaras V, Tsihrintzis V. Spatial prediction of nitrate pollution in groundwaters using neural networks and GIS: An application to South Rhodope aquifer (Thrace, Greece). Hydrol Proce 2009; 23: $372-383$.

22. Huang J, Xu J, Liu X, et al. Spatial distribution pattern analysis of groundwater nitrate nitrogen pollution in Shandong intensive farming regions of China using neural network method. Math Comput Model 2011; 54: 995-1004

23. Al-Mahallawi K, Mania J, Hani A, et al. Using of neural networks for the prediction of nitrate groundwater contamination in rural and agricultural areas. Environ Earth Sci 2012; 65: 917-928.

24. Akhovat A, Mousavi SM. Modeling and Simulation of Arsenic, Chromium and Cadmium Removal from Water by Nanofiltration Process by Artificial Neural Networks. 1st Environmental remediation technologies conference, Sharif university of technology, Iran 2011: [In Persian].

25. Derakhshan S, Gholami V, Darvari Z. Simulation of Ground Water Salinity by Using Artificial Neural Network (ANN) on the Mazandaran province coasts. Irrig Sci Eng 2013; 36(2): 61-70 [In Persian].

26. Karimi nezhad MT, Tali MG, Mahmoudi MH, et al. Spatial Variability of as and $\mathrm{Cd}$ Concentrations in Relation to Land Use, Parent Material and Soil Properties in Topsoils of Northern Ghorveh, Kurdistan Province, Iran. World Appl Sci J 2010; 11: 1105-1113.

27. Jalali Lichaei M, Nabi-Bidhendi M. Comparison between multiple linear regression and artificial neural networks for porosity and permeability estimation. Geosci 2006; 61: 140-149 [In Persian]

28. Way C. Standard methods for the examination of water and wastewater. Water Environment Federation, Secaucus, 2012 NJ, USA.

29. Giacomino A, Malandrino M, Abollino O, et al. An approach for arsenic in a contaminated soil: speciation, fractionation, extraction and effluent decontamination. Environ Pollut 2010; 158: 416-423.

30. Olsen SR. Estimation of available phosphorus in soils by extraction with sodium bicarbonate. 1954.

31. Jackson M, Soil Chemical Analysis, 1967. Pub. By Prentice-Hall of India Pvt. Ltd., New Delhi, India. pp, 41196.

32. Walkley A, Black IA. An examination of the Degtjareff method for determining soil organic matter, and a proposed modification of the chromic acid titration method. Soil Sci 1934; 37: 29-38.

33. Mehra O, Jackson, M. Iron oxide removal from soils and clays by a dithionite-citrate system buffered with sodium bicarbonate. Proc. 7th Nat. Conf. Clays 1960; 317-327.

34. McKeague J, Day JH. Dithionite-and oxalate-extractable $\mathrm{Fe}$ and $\mathrm{Al}$ as aids in differentiating various classes of soils. Canadian J Soil Sci 1996; 46: 13-22.

35. Bower CA, Reitemeier R, Fireman M. Exchangeable cation analysis of saline and alkali soils. Soil Sci 1952; 73: $251-262$.

36. Day PR. Particle Fractionation and Particle-Size Analysis. Methods of Soil Analysis. Part 1. Physical and Mineralogical Properties, Including Statistics of Measurement and Sampling (ed C. A. Black), 1965; pp. 545-567. American Society of Agronomy, Soil Science Society of America.

37. Zhu YM, Lu X, Zhou Y. Suspended sediment flux modeling with artificial neural network: An example of the Longchuanjiang River in the Upper Yangtze Catchment. China Geo 2007; 84: 111-125.

38. Dastorani MT, Azimi Fashi K, Talebi A, Ekhtesasi MR. Estimation of Suspended Sediment Using Artificial Neural Network (Case Study: Jamishan Watershed in Kermanshah). J Watershed Manag Res 2012; 3(6): 61-74 [In Persian].

39. Demuth H, Beale M. Neural Network Toolbox (Version 4) For Use with Matlab. The Mathworks, Inc Available online at: ttps://wwwmathworkscom/help/pdf_doc/nnet/ nnet_ugpdf 1998.

40. Minasny B, McBratney A. The neuro-m method for fitting neural network parametric pedotransfer functions. Soil Sci Soc Am J 2002; 66: 352-361.

41. Back B, Back BJR. Financial statement planning in the presence of tax constraints. Euro J Oper Res 1995; 85: 66-81.

42. Missaghi.F, Mohammadi.k. Estimation of groundwater levels using conventional interpolation techniques and comparison with geostatistics technique. Twenty-first meeting on Earth Sciences Geo Survey and Min Explo of Country 2002: 588-590.

43. Hassani Pak AA. Geostatistics. Tehran University Press 1998: 328 [In Persian]

44. A MS, Abyaneh.H TZ. Evaluation of geostatistical methods for estimating electrical conductivity and $\mathrm{pH}$ of stream waters in Hamedan-Bahar plain. J Water Soil Conser 2009;16: 169-187.

45. Khodakarami L, Soffianian AR, Mohamadi T, Mirghafari NA. Study of heavy metals concentration Copper, Zinc and Arsenic soil using GIS and RS techniques (Case study: Kaboudarahang, Razan and Khonjin- Talkhab

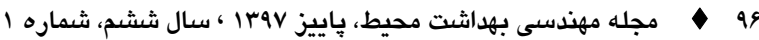




$$
\text { سامان مرادى و همكاران }
$$

catchment in Hamedan province). Appl RS GIS Tech Nat Resour Sci 2011; 2(1): 79-89 [In Persian].

46. Giacomino A, Malandrino M, Abollino O, et al. An approach for arsenic in a contaminated soil: speciation, fractionation, extraction and effluent decontamination. Environ Poll 2010; 158: 416-423.

47. Wauchope R. Fixation of arsenical herbicides, phosphate, and arsenate in alluvial soils. J Environ Qual 1975; 4: 355-358.

48. Álvarez-Benedí J, Bolado S, Cancillo I, et al. Adsorption-desorption of arsenate in three Spanish soils. Vadose Zone J 2005; 4: 289-290.

49. Jain A, Loeppert RH. Effect of competing anions on the adsorption of arsenate and arsenite by ferrihydrite. Environ Qual 2000; 29: 1422-1430.

50. Smith E, Naidu R, Alston A. Chemistry of arsenic in soils: I. Sorption of arsenate and arsenite by four Australian soils. Environ Qual 1999; 28: 1719-1726.

51. Anawar HM, Akai J, Sakugawa H. Mobilization of arsenic from subsurface sediments by effect of bicarbonate ions in groundwater. Chemo 2004; 54: 753762 .

52. Kinniburgh D, Jackson M, Syers J. Adsorption of alkaline earth, transition, and heavy metal cations by hydrous oxide gels of iron and aluminum. Soil Sci Soc Am J 1976; 40: 796-799.

53. Kinniburgh D, Smedley P. A review of the source, behaviour and distribution of arsenic in natural waters. Appl Geo 2002 17:517-68.

54. Frost R, Griffin R. Effect of $\mathrm{pH}$ on adsorption of arsenic and selenium from landfill leachate by clay minerals. Soil Sci Soc Am J 1977;41: 53-57.
55. Majedi S, Soori b, Shiradi A. The zoning of arrsenic presence in some calcareous soils of Qorveh plain using logestic regression. Iranian J Soil Res. 2013; 27: 227-238 [In Persian].

56. Anagu I, Ingwersen J, Utermann J, et al. Estimation of heavy metal sorption in German soils using artificial neural networks. Geod 2009; 152: 104-12.

57. Schaap MG. Using neural network to predict soil water retention and soil hydraulic conductivity. Soil Till Res 1998; 47: 37- 42.

58. Robles LA, Ortega JC, Fu JS, et al. A hybrid ARIMA and artificial neural networks model to forecast particulate matter in urban areas: The case of Temuco, Chile. Atmos Environ 2008; 42: 8331- 340.

59. Elkamel A, Abdul-Wahab S, Bouhamra W, et al Measurement and prediction of ozone levels around a heavily industrialized area: A neural network approach. Advan Environ Res 2001; 5: 47-59.

60. Chaloulakou A, Grivas G, Spyrellis N. Neural Network and Multiple Regression Model for $\mathrm{PM}_{10}$ Prediction in Athens: A Comparative Assessment. J Air Waste Manag Associ 2003; 53 (10): 1183-190.

61. Cai M, Yin Y, Xie M. Prediction of hourly air pollutant concentrations near urban arterials using artificial neural network approach. Transport Res D 2009. 14: 32-41.

62. Purkait B, Kadam S, Das S. Application of artificial neural network model to study arsenic contamination in groundwater of Malda District, Eastern India. J Environ Inform 2008; 12: 140-49.

63. Hosseini SM, Mahjouri N. Developing a fuzzy neural network-based support vector regression (FNN-SVR) for regionalizing nitrate concentration in groundwater. Environ Monit Assess 2014; 186: 3685-699. 